\title{
Android-Based Remote Control Solar Power Plant Panels with Direct Current System Installation
}

\section{Panel Pembangkit Listrik Tenaga Matahari dengan Instalasi Sistem Arus Searah Kendali Jarak Jauh Berbasis Android}

\author{
Yusril Afandi ${ }^{1}$, Jamaaluddin Jamaaluddin ${ }^{2}$ \\ \{yusrilafandi26@gmail.com ${ }^{1}$, jamaaluddin@umsida.ac.id ${ }^{2}$ \}
}

Program Studi Teknik Elektro, Fakultas Sains dan Teknologi, Universitas Muhammadiyah Sidoarjo

\begin{abstract}
Energy hot sun very overflow especially in area with climate tropical as indonesia that always exposed rays throughout years. This is a source energy that could on developed. on research aimed at to make it easier and knowing damage panel generator electric power sun more early so that soon get to do troubleshooting early before damage continue with use microcontroller NodeMCU right has been IOT designed component additional sensor INA219 gauge current, voltage, lux intensity light is snown software application BLYNK in smartphone. the results research is toll monitoring read high low battery and lamp. In the result measurement this will is snown menu application BLYNK that has been designed.
\end{abstract}

Keywords - Electric Current; Monitoring; NodeMCU; Voltage; PLTS

\begin{abstract}
Abstrak. Energi panas matahari sangat melimpah terutama di daerah dengan iklim tropis seperti Indonesia yang selalu terpapar sinar matahari sepanjang tahun. Ini merupakan sumber energi yang dapat dikembangkan. Pada penelitian ini ditujukan untuk mempermudah dan mengetahui kerusakan pada panel pembangkit listrik tenaga surya lebih awal, sehingga dapat segera melakukan troubleshooting lebih dini sebelum kerusakan lebih lanjut dengan menggunakan mikrokontroller nodemcu yang dapat di IOT kan dengan komponen tambahan sensor INA219 sebagai pengukur arus dan tegangan, dan sensor lux sebagai pengukur intensitas cahaya matahari.yang dapat ditampilkan pada software aplikasi BLYNK di smartphone. Hasil pada penelitian ini adalah alat dapat memonitoring dan membaca tinggi rendahnya arus dan tegangan pada baterai serta lampu. pada hasil pengukuran tersebut akan ditampilkan pada menu aplikasi BLYNK yang telah dirancang.
\end{abstract}

Kata Kunci - Arus Listrik; Monitoring; NodeMCU; Tegangan; PLTS

\section{I.PENDAHULUAN}

Pemanfaatan energi panas matahari di daerah yang beriklim tropis seperti di negara Indonesia sangatlah bagus untuk diterapkan [1]. Panas matahari menjadi sebuah sumber energi terbarukan yang sangat mempunyai potensi untuk dikembangkan pada saat ini. Contoh salah satunya yaitu pemanfaatan penggunaan energi panas sinar matahari yang menghasilkan energi listrik alternatif yang sering disebut di lingkungan masyarakat dengan nama panel surya[2].

Untuk penerapan penggunaan dari sumber energi listrik alternatif sangat berpotensi mengingat dari sumber panas matahari yang rata rata di wilayah negara Indonesia sangat melimpah [3].energi panas matahari cukup banyak dengan intensitas radiasi panas matahari yang rata rata cukup baik untuk setiap harinya di setiap wilayah Indonesia[4]

Penelitian ini menerapkan sistem listrik arus searah bertegangan DC dengan dilengkapi kontrol monitoring jarak jauh dimana untuk melakukan pembacaan arus, tegangan dan intesitas di baca sensor INA219 dan sensor lux bh1750 yang kemudian di proses oleh miktrokontroller NodeMCU yang nantinya dikontrol oleh relay, kemudian interface dari aplikasi blynk yang terkoneksi internet akan menampilkan hasil monitoring arus, tegangan, intensitas dan mematikan/menghidupkan lampu secara otomatis.

Energi panas matahari adalah sebuah energi terbarukan yang jarang digunakan oleh banyak masyarakat padahal energi tersebut mudah, murah dan paling pentingnya tidak merusak ekosistem lingkungan hidup [5].

Sebuah sistem PLTS terdiri dari panel surya, SCC (solar charger controller), baterai/acuu dan beban. Sistem PLTS merupakan sistem yang pengubah sinar matahari menjadi energi listrik arus searah bertegangan DC untuk menyuplai beban pada lampu[6].

Panel surya merupakan sebuah alat untuk merubah energi dari panas matahari menjadi energi listrik alternatif. Panel surya adalah alat yang berfungsi untuk mengkonversi ataupun merubah energi panas dari matahari menjadi energi listrik secara langsung. [7].

Baterai adalah komponen PLTS yang diperlukan untuk menyimpan energi listrik yang dihasilkan oleh panel surya pada siang hari untuk kemudian digunakan pada malam hari. Ketersediaan produk ini secara nasional sudah mencukupi baik dari sisi kapasitas dan distribusi[6].

Lampu merupakan alat penerangan disaat gelap yang dibutuhkan dalam kehidupan sehari hari. lampu digunakan di semua tempat dan wilayah yang ada di bumi.[8] 
Mikrokontroller NodeMCU merupakan sebuah board elektronika yang berbasis ESP8266 yang mampu melakukan koneksi internet wifi dan menjalankan fungsi mikrokontroller. Mikrokontroller nodemcu mempunyai beberapa pin input dan output yang dapat dijadikan dalam sebuah alat kontroling maupun monitoring dari internet of things. Mikrokontroller NodeMCU dapat di program mengunakan aplikasi arduino, menggunakan Arduino ide. Untuk bentuk fisi miktrokontroller nodemcu ada port usb atau usb mini sehingga bisa memudahkan pemogramannya [9].

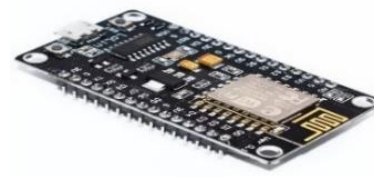

Gambar 1. Mikrokontroller Nodemcu[9].

Sensor INA219 adalah senosr yang mengukur arus, tegangan dan daya pada suatu rangkaian yang sudah dilengkapi dengan komunikasi i2c. sensor ini terdiri dari beberapa pin yaitu vin + , vin -, scl, sda, gnd, dan vcc yang masing masing mempunyai fungsi tersendiri.untuk pengukuran besaran dari daya sensor ini dapat mengukur lebih dari 75 watt [10].

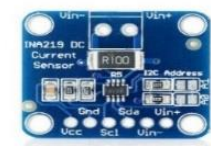

Gambar 2. Sensor INA219[11].

Sensor lux adalah sebuah sensor yang digunkan untuk mengukur intensitas cahaya disekitarnya.sensor ini menggunkan satuan I2C untuk komunikasi dengan mikrokontroller atau minimum sistem.jangkauannya cukup lebar yaitu antara 1 - 65535 lux.lux berarti besaran dari luas area 1 meter persegi[12].

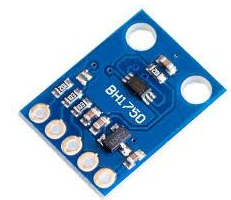

Gambar 3. Sensor Lux Tipe BH 1750[12].

\section{II.METODE}

\section{A. Tahapan penelitian}

1. Pertama yaitu penyedian komponen yang dibutuhkan untuk melakukan desain alat.

2. Kedua yaitu perancangan system PLTS seperti panel PV, SCC, Aki, dan mikrokontroller.

3. Ketiga yaitu pegujian sistem. Melakukan beberapa uji coba daya keluaran dari PLTS, mikrokontroller nodemcu, sensor INA219, sensor lux bh 1750, beban lampu DC dan Aki.

4. Keempat yaitu pengujian sistem sumber daya energi alternatif dari PLTS.

\section{B. Diagram blok sistem.}

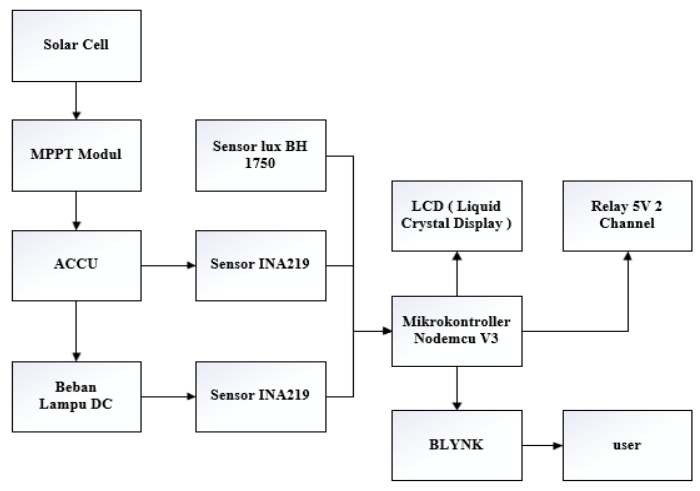

\section{Flowchart sistem}

Gambar 4. Diagram Blok Sistem. 
Penjelasan flowchart di atas :

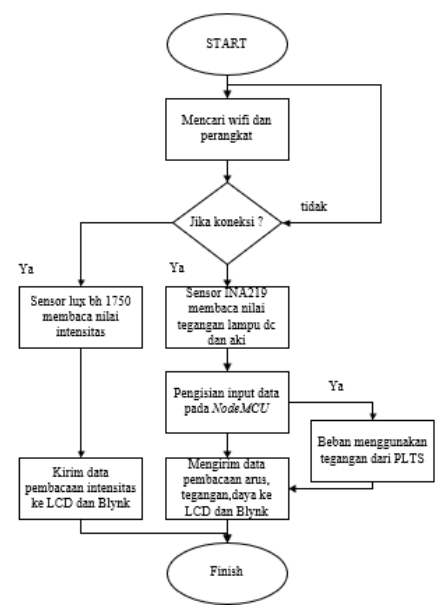

Gambar 5. Flowchart Sistem.

1. Start melakukan Penyettingan Autentikasi, Ssid dan Password Wifi dan Mengupload Code yang sudah dibuat pada Software Arduino.

2. Jika belum terhubung, maka melakukan penyettingan kembali pada Software Arduino.

3. Jika sudah terhubung dengan internet wifi, Sensor INA219 dan Sensor lux bh1750 akan melakukan pembacaan.

4. Sensor INA219 akan membaca nilai keluaran tegangan dan arus pada lampu dan aki.

5. Sensor lux bh1750 akan membaca nilai keluaran intensitas cahaya pada matahari.

6. Nilai keluaran pada Tegangan, Arus, Daya dan intensitas akan ditampilkan pada LCD 20X4 I2C dan aplikasi Blynk supaya bisa dimonitoring setiap waktu.

7. Finish

\section{Rangkaian keseluruhan sistem}

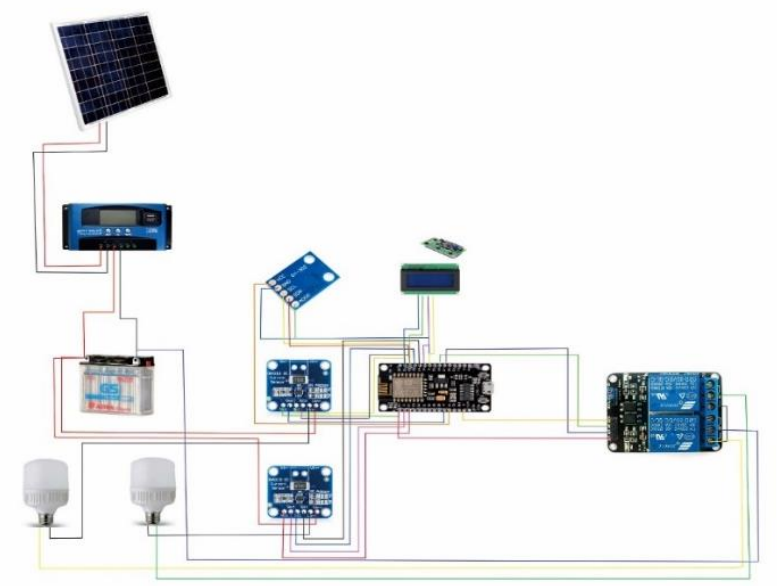

Gambar 6. Rangkaian Keseluruhan Sistem.

1. Panel surya yang dipakai sebesar $50 \mathrm{wp}$ untuk mengubah energi panas matahari menjadi energi listrik sebesar 12 volt.

2. SCC berfungsi untuk pengecasan aki jika terkena panas matahari.

3. AKI sebagai penyuplay daya untuk nodemcu dan lampi DC.

4. Nodemcu akan mengirimkan data ke aplikasi blynk dan LCD untuk menampilkan hasil output arus dan tegangan yang sudah dibaca sensor.

5. Sensor INA219 untuk membaca nilai tegangan yang keluar dari output aki dan lampu DC untuk mengirimkan data jika tegangan kurang/lebih dari 10VDC dan juga mengukur arus beban.

6. Sensor lux bh 1750 untuk membaca nilai dari intensitas cahaya matahari.

7. Relay 2 channel untuk penghubung atau pemutus sementara aliran listrik dari system PLTS dan menghidupkan/mematikan beban lampu DC lewat aplikasi BLYNK.

8. Lampu sebagai beban pada plts. 


\section{HASIL DAN PEMBAHASAN}

\section{A. Desain perancangan alat yang sudah dibuat.}

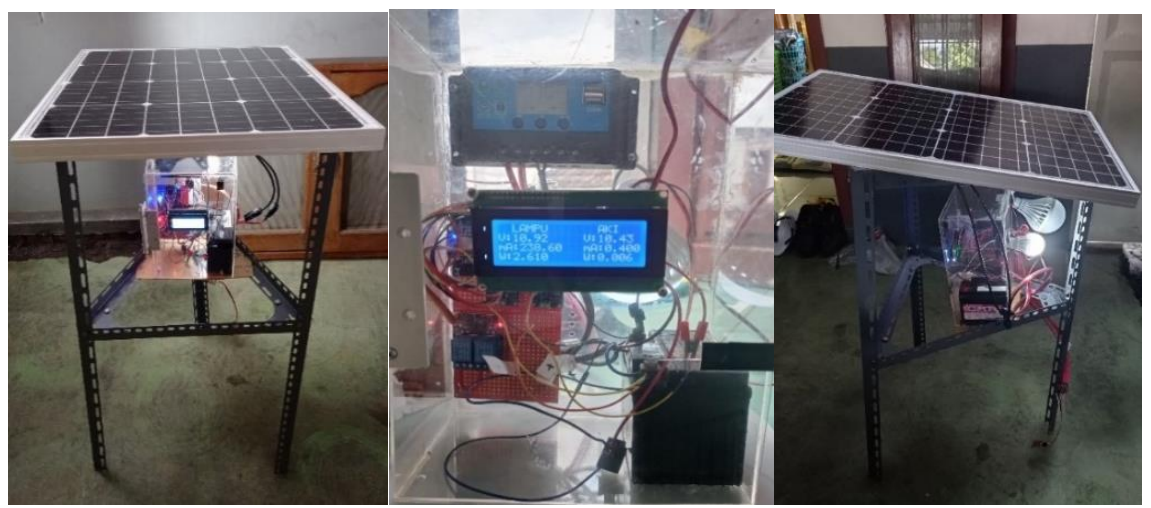

Gambar 7. Desain perancangan alat yang sudah dibuat.

Sistem alat yang sudah dirancang akan dilakukan Pengujian dan Pembahasan. Tahap ini melakukan Pengujian supaya mengetahui cara kerja beserta mengetahui Keluaran pada Perancangan sistem dan Pengambilan data dilakukan pada bagian-bagian secara keseluruhan nantinya akan dianalisa.

\section{B. Pengujian sistem plts ( pembangkit listrik tenaga surya ).}

Pada tahap ini dilakukan pengujian beban dari catu daya PLTS yang dilakukan secara otomatis. apabila sumber PLTS mendapatkan energi cahaya matahari maka dilakukan pengolahan energi oleh SCC yang kemudian di simpan di baterai atau aki. Pengujian ini dilakukan untuk mengubah apakah sistem PLTS dapat berfungsi secara normal.

Prosedur pengujian sistem PLTS yaitu :

1. Menekan tombol on pada panel box, pada saat kondisi starting mikrokontroller NodeMCU melakukan koneksi dengan aplikasi Blynk dengan terhubung dengan internet dan memproses data dari sensor INA219.

2. Jika lampu indicator pada sistem PLTS menyala maka menandakan bahwa daya PLTS terhubung menyuplai ke beban.

3. Ketika tegangan PLTS melemah maka seluruh sistem akan redup dan mati secara otomatis

4. Inilah gambar Ketika panel PLTS pada saat menyala dan mati.
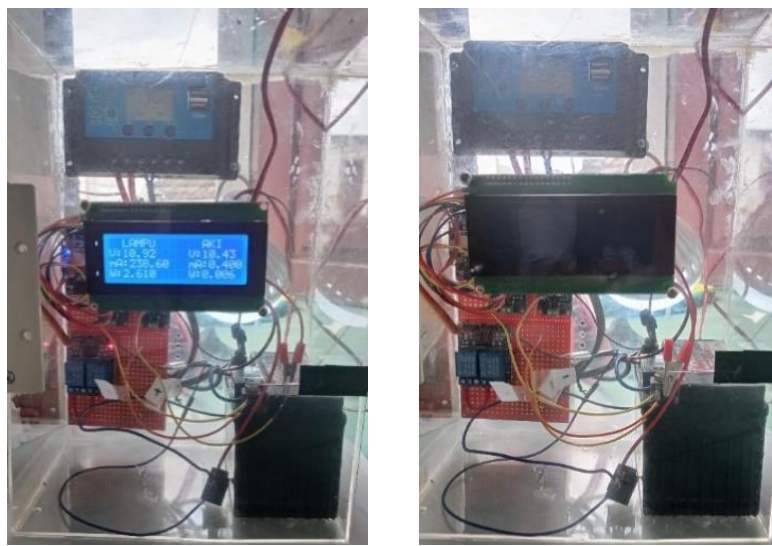

Gambar 8. Panel PLTS Ketika Menyala Dan Mati.

Berdasarkan tabel 1. pengujian sistem PLTS diatas dilakukan pada hari senin, 22 februari 2021 selama 10 jam di dapatkan data daya PLTS menyuplai ke beban dari pukul 08.00 wib sampai 17.00 wib. rata rata pengukuran yang didapatkan pada pengeluaran aki dan lampu.

Tabel 1. Pengujian PLTS Dan Melakukan Pengukuran Keluaran.

\begin{tabular}{llllllll}
\hline No Jam & Cuaca & $\begin{array}{c}\text { Kondisi Aliran } \\
\text { Listrik PLTS }\end{array}$ & & Pengukuran Output Aki & \multicolumn{2}{c}{$\begin{array}{c}\text { Pengukuran Output } \\
\text { Lampu }\end{array}$} \\
\cline { 3 - 7 } & & V & A & W & V & A & W \\
\hline
\end{tabular}


Procedia of Engineering and Life Science Vol. 1. No. 2 Juni 2021

Seminar Nasional \& Call Paper Fakultas Sains dan Teknologi (SENASAINS 2nd)

Universitas Muhammadiyah Sidoarjo

\begin{tabular}{cccccccccc}
\hline 1 & 08.00 & Mendung & ON & 11.34 & 0,15 & 1,96 & 10,34 & 0,16 & 1,65 \\
\hline 2 & 08.30 & Mendung & ON & 11.29 & 0,15 & 1,94 & 10,27 & 0,16 & 1,64 \\
\hline 3 & 09.00 & Mendung & ON & 11,15 & 0,14 & 1,86 & 10,03 & 0,14 & 1,40 \\
\hline 4 & 09.30 & Mendung & ON & 11,15 & 0,14 & 1,88 & 10,02 & 0,14 & 1,42 \\
\hline 5 & 10.00 & Cerah & ON & 12,10 & 0,30 & 4,0 & 11,25 & 0,32 & 3,6 \\
\hline 6 & 10.30 & Cerah & ON & 12,82 & 0,37 & 3,44 & 10,92 & 0,24 & 2,62 \\
\hline 7 & 11.00 & Cerah & ON & 12,66 & 0,34 & 3,22 & 10,75 & 0,22 & 2,36 \\
\hline 8 & 11.30 & Cerah & ON & 13,88 & 0,66 & 8,66 & 13,96 & 0,64 & 8,93 \\
\hline 9 & 12.00 & Cerah & ON & 13,81 & 0,60 & 8,17 & 13,74 & 0,59 & 8,10 \\
\hline 10 & 12.30 & Cerah & ON & 12,22 & 0,40 & 6,26 & 11,82 & 0,36 & 4,25 \\
\hline 11 & 13.00 & Cerah & ON & 11,11 & 0,30 & 3,44 & 10,72 & 0,22 & 2,35 \\
\hline 12 & 13.30 & Mendung & ON & 11,21 & 0,23 & 1,39 & 10,41 & 0,18 & 1,87 \\
\hline 13 & 14.00 & Mendung & ON & 11,32 & 0,21 & 1,30 & 10,3 & 0,17 & 1,75 \\
\hline 14 & 14.30 & Mendung & ON & 11,22 & 0,18 & 1,09 & 10,32 & 0,17 & 1,75 \\
\hline 15 & 15.00 & Mendung & ON & 11,23 & 0,19 & 1,08 & 10,3 & 0,17 & 1,75 \\
\hline 16 & 15.30 & Mendung & ON & 11,19 & 0,17 & 1,06 & 10,31 & 0,17 & 1,75 \\
\hline 17 & 16.00 & Mendung & ON & 11,19 & 0,18 & 1,08 & 10,23 & 0,16 & 1,63 \\
\hline 18 & 16.30 & Mendung & ON & 11,18 & 0,20 & 1,10 & 10,20 & 0,16 & 1,63 \\
\hline 19 & 17.00 & Mendung & ON & 11,18 & 0,20 & 1,10 & 10,2 & 0,16 & 1,63 \\
\hline & Rata Rata & ON & 11,16 & 0,26 & 2,84 & 10,84 & 0,23 & 2,74 \\
\hline
\end{tabular}

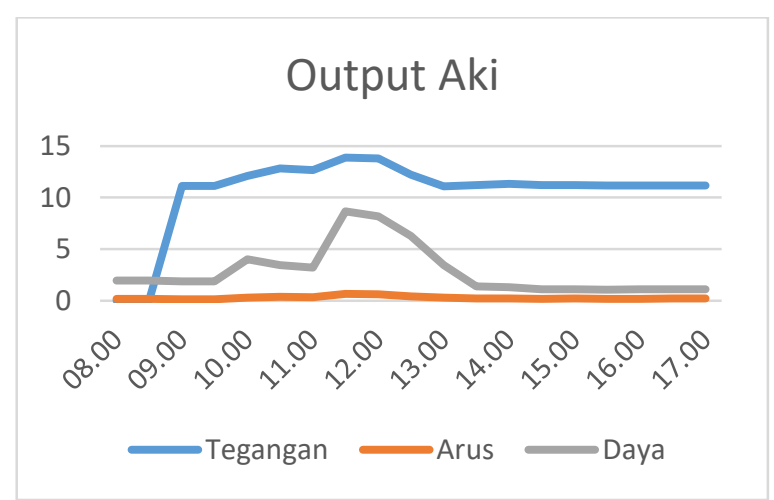

Gambar 9. Grafik Pengukuran Aki.

Pada gambar grafik 9. diatas dilakukan pengukuran keluaran dari Aki didapatkan data yang dimana rata rata diperoleh tegangan $11,16 \mathrm{~V}$, arus sebesar $0,26 \mathrm{~A}$ dan daya $2,84 \mathrm{~W}$ dari 08.00 sampai 17.00.

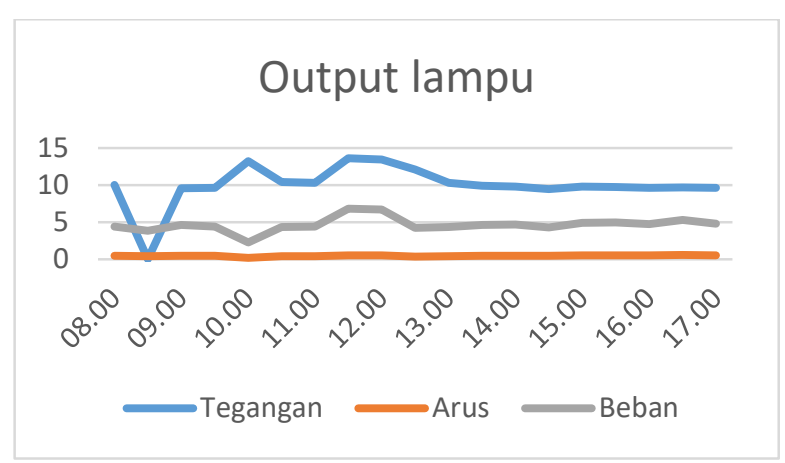

Gambar 10. Grafik Pengukuran Lampu.

Pada gambar grafik 10. diatas dilakukan pengukuran keluaran pada lampu di mulai pada pukul 08.00 sampai 17.00. pada grafik tersebut didapatkan data rata rata tegangan $10,84 \mathrm{~V}$, arus sebesar $0,23 \mathrm{~A}$ dan daya $2,74 \mathrm{~W}$.

\section{Pengujian sensor ina219}


Procedia of Engineering and Life Science Vol. 1. No. 2 Juni 2021

Seminar Nasional \& Call Paper Fakultas Sains dan Teknologi (SENASAINS 2nd)

Universitas Muhammadiyah Sidoarjo

Pengujian sensor INA219 dapat membaca nilai keluaran dari tegangan dan arus, dilakukan untuk mendapatkan keakurasian sensor apakah sensor sesuai dengan alat sesungguhnya, dengan demikian akan disimpulkan keakurasiannya

Tabel 2. Pengujian Sensor INA219 Untuk Pengukuran Tegangan.

\begin{tabular}{|c|c|c|c|c|c|c|c|c|c|c|c|c|c|c|c|c|c|}
\hline \multirow[t]{2}{*}{ No } & \multirow[t]{2}{*}{$\begin{array}{l}\text { Output } \\
\text { Beban }\end{array}$} & \multicolumn{2}{|c|}{$\begin{array}{c}\text { Pengujian } \\
\text { Ke-1 }\end{array}$} & \multicolumn{2}{|c|}{$\begin{array}{c}\text { Pengujian } \\
\mathrm{Ke}-2\end{array}$} & \multicolumn{2}{|c|}{$\begin{array}{c}\text { Pengujian } \\
\text { ke-3 }\end{array}$} & \multicolumn{2}{|c|}{$\begin{array}{c}\text { Pengujian } \\
\mathrm{Ke}-4\end{array}$} & \multicolumn{2}{|c|}{$\begin{array}{c}\text { Pengujian } \\
\mathrm{Ke}-5\end{array}$} & \multicolumn{2}{|c|}{$\begin{array}{l}\text { Rata Rata } \\
\text { Tegangan }\end{array}$} & \multicolumn{4}{|c|}{$\begin{array}{l}\text { Standart } \\
\text { Deviasi }\end{array}$} \\
\hline & & $\begin{array}{c}\text { Sensor } \\
\text { INA } \\
219 \\
\text { (V) }\end{array}$ & $\begin{array}{l}\text { Alat } \\
\text { Standart } \\
\text { (V) }\end{array}$ & $\begin{array}{c}\text { Sensor } \\
\text { INA } \\
219 \\
\text { (V) }\end{array}$ & $\begin{array}{l}\text { Alat } \\
\text { Standart } \\
\text { (V) }\end{array}$ & $\begin{array}{c}\text { Sensor } \\
\text { INA } \\
219 \\
(\mathrm{~V})\end{array}$ & $\begin{array}{l}\text { Alat } \\
\text { Standart } \\
\text { (V) }\end{array}$ & $\begin{array}{c}\text { Sensor } \\
\text { INA } \\
219 \\
\text { (V) }\end{array}$ & $\begin{array}{l}\text { Alat } \\
\text { Standart } \\
\text { (V) }\end{array}$ & $\begin{array}{c}\text { Sensor } \\
\text { INA } \\
219 \\
(\mathrm{~V})\end{array}$ & $\begin{array}{l}\text { Alat } \\
\text { Standart } \\
\text { (V) }\end{array}$ & $\begin{array}{c}\text { Sensor } \\
\text { INA } \\
219 \\
(\mathrm{~V})\end{array}$ & $\begin{array}{l}\text { Alat } \\
\text { Standart } \\
\text { (V) }\end{array}$ & $\begin{array}{c}\text { Sensor } \\
\text { INA } \\
219 \\
(\mathrm{~V})\end{array}$ & $\begin{array}{l}\text { Alat } \\
\text { Standart } \\
\text { (V) }\end{array}$ & Deviasi & $\begin{array}{c}\text { Persen } \\
\text { Ketepatan \% }\end{array}$ \\
\hline 1 & Aki & 12,30 & 12,35 & 12,31 & 12,35 & 12,31 & 12,34 & 12,31 & 12,35 & 12,31 & 12,35 & 12,30 & 12,34 & 0,02 & 0,02 & 0,04 & $99,7 \%$ \\
\hline 2 & Lampu & 13,94 & 13,90 & 13,98 & 13,96 & 13,96 & 13,96 & 13,98 & 13,97 & 13,86 & 13,86 & 13,94 & 13,93 & 0,02 & 0,01 & 0,01 & $99,9 \%$ \\
\hline
\end{tabular}

Berdasarkan pada tabel 2 diatas melakukan pengukuran keluaran tegangan Aki dan lampu dilakukan sebanyak 5 kali, dimana didapatkan standart deviasi dari sensor INA219 $=0,02-0,02$ Sedangkan standart deviasi dari alat standart $=0,01-0,02$, untuk tingkat akurasi dari sensor sebesar 99,7 \% - 99,9\% Kesimpulan dari pengujian pada sensor INA219 dan AVO meter menunujukan angka yang hampir sama.

Tabel 3. Pengujian Sensor INA 219 Untuk Pengukuran Arus.

\begin{tabular}{|c|c|c|c|c|c|c|c|c|c|c|c|c|c|c|c|c|c|}
\hline \multirow[t]{2}{*}{ No } & \multirow[t]{2}{*}{$\begin{array}{l}\text { Output } \\
\text { Beban }\end{array}$} & \multicolumn{2}{|c|}{$\begin{array}{c}\text { Pengujian } \\
\mathrm{Ke}-1\end{array}$} & \multicolumn{2}{|c|}{$\begin{array}{c}\text { Pengujian } \\
\mathrm{Ke}-2\end{array}$} & \multicolumn{2}{|c|}{$\begin{array}{c}\text { Pengujian } \\
\text { ke-3 }\end{array}$} & \multicolumn{2}{|c|}{$\begin{array}{c}\text { Pengujian } \\
\mathrm{Ke}-4\end{array}$} & \multicolumn{2}{|c|}{$\begin{array}{c}\text { Pengujian } \\
\mathrm{Ke}-5\end{array}$} & \multicolumn{2}{|c|}{$\begin{array}{c}\text { Rata Rata } \\
\text { Arus }\end{array}$} & \multicolumn{2}{|c|}{$\begin{array}{c}\text { Standart } \\
\text { deviasi }\end{array}$} & \multirow[b]{2}{*}{ Deviasi } & \multirow[b]{2}{*}{$\begin{array}{c}\text { Persen } \\
\text { Ketepatan \% }\end{array}$} \\
\hline & & $\begin{array}{c}\text { Sensor } \\
\text { INA } \\
219 \\
(\mathrm{~mA})\end{array}$ & $\begin{array}{l}\text { Alat } \\
\text { Standart } \\
(\mathrm{mA})\end{array}$ & $\begin{array}{l}\text { Sensor } \\
\text { INA } \\
219 \\
(\mathrm{~mA})\end{array}$ & $\begin{array}{l}\text { Alat } \\
\text { Standart } \\
(\mathrm{mA})\end{array}$ & $\begin{array}{l}\text { Sensor } \\
\text { INA } \\
219 \\
(\mathrm{~mA})\end{array}$ & $\begin{array}{l}\text { Alat } \\
\text { Standart } \\
(\mathrm{mA})\end{array}$ & $\begin{array}{c}\text { Sensor } \\
\text { INA } \\
219 \\
(\mathrm{~mA})\end{array}$ & $\begin{array}{c}\text { Alat } \\
\text { Standart } \\
(\mathrm{mA})\end{array}$ & $\begin{array}{c}\text { Sensor } \\
\text { INA } \\
219 \\
(\mathrm{~mA})\end{array}$ & $\begin{array}{c}\text { Alat } \\
\text { Standart } \\
(\mathrm{mA})\end{array}$ & $\begin{array}{c}\text { Sensor } \\
\text { INA } \\
219 \\
(\mathrm{Ma} \\
)\end{array}$ & $\begin{array}{c}\text { Alat } \\
\text { Standart } \\
(\mathrm{mA})\end{array}$ & $\begin{array}{c}\text { Sensor } \\
\text { INA } \\
219 \\
(\mathrm{~mA})\end{array}$ & $\begin{array}{c}\text { Alat } \\
\text { Standart } \\
(\mathrm{mA})\end{array}$ & & \\
\hline 1 & Aki & 152 & 150 & 140 & 140 & 150 & 148 & 150 & 146 & 150 & 148 & 148,4 & 340,8 & 2,38 & 1,11 & 1,6 & $99 \%$ \\
\hline 2 & Lampu & 355 & 340 & 344 & 340 & 336 & 330 & 335 & 330 & 330 & 334 & 146,8 & 334 & 3,14 & 4,45 & 6,8 & $98 \%$ \\
\hline
\end{tabular}

Berdasarkan pada tabel pengujian 3 diatas melakukan pengukuran keluaran arus lampu dan aki dilakukan sebanyak 5 kali, dimana didapatkan standart deviasi dari sensor INA219=2,38-3,14 sedangkan standart deviasi dari alat standart sebesar $=1,1$ untuk tingkat akurasi sensor sebesar 98-99 \%. Kesimpulan dalam pengujian sensor INA219 dan AVO meter menunjukan eror pembacaan sebesar $2 \%$.

\section{Pengujian sensor lux bh1750}

Sensor lux bh1750 berfungsi sebagai sensor pembaca intesitas cahaya matahari dengan satu lux (lx) yang mempunyai jangkauan pengukuran dari 0-65535.pengujian ini dilakukan 10 jam dari pukul 08.00 - 17.00. jika intesitas cahaya matahari semakin cerah dan dekat maka akan semakin tinggi pengukuran sensor lux bh1750 dan jika semakin rendah intesitas cahaya matahari maka pengukuran semakin sedikit. Hasil keluaran sensor lux bh1750 akan di data mikrokontroller NodeMCU.

Tabel 4. Pengukuran Nilai Intensitas Pada Cahaya Matahari.

\begin{tabular}{|c|c|c|c|c|c|}
\hline No & Waktu & $\begin{array}{c}\text { Intensitas } \\
\text { Cahaya } \\
\text { (lux ) }\end{array}$ & $\begin{array}{c}\text { Sun } \\
\text { Azimuth }\end{array}$ & $\begin{array}{c}\text { Sun } \\
\text { Elevation }\end{array}$ & Cuaca \\
\hline 1 & 08.00 & 3978 & $66,5^{\circ}$ & $34,4^{\circ}$ & Cerah \\
\hline 2 & 08.30 & 4506 & $63,1^{\circ}$ & $41,1^{\circ}$ & Cerah \\
\hline 3 & 09.00 & 4082 & $58,5^{\circ}$ & $47,6^{\circ}$ & Cerah \\
\hline 4 & 09.30 & 5354 & $52,3^{\circ}$ & $53,7^{\circ}$ & Cerah \\
\hline 5 & 10.00 & 6890 & $43,8^{\circ}$ & $59,3^{\circ}$ & Cerah \\
\hline 6 & 10.30 & 6492 & $31,9^{\circ}$ & $63,8^{\circ}$ & Cerah \\
\hline 7 & 11.00 & 6572 & $16,0^{\circ}$ & $66,9^{\circ}$ & Cerah \\
\hline 8 & 11.30 & 10020 & $357,3^{\circ}$ & $67,8^{\circ}$ & Cerah \\
\hline 9 & 12.00 & 8226 & $339,0^{\circ}$ & $66,2^{\circ}$ & Cerah \\
\hline 10 & 12.30 & 7510 & $324,3^{\circ}$ & $62,6^{\circ}$ & Cerah \\
\hline 11 & 13.00 & 5196 & $313,5^{\circ}$ & $57,7^{\circ}$ & Cerah \\
\hline 12 & 13.30 & 4180 & $305,8^{\circ}$ & $52,0^{\circ}$ & cerah \\
\hline 13 & 14.00 & 4075 & $300,1^{\circ}$ & $45,7^{\circ}$ & cerah \\
\hline 14 & 14.30 & 4275 & $295,9^{\circ}$ & $39,2^{\circ}$ & cerah \\
\hline 15 & 15.00 & 3032 & $292,7^{\circ}$ & $32,4^{\circ}$ & cerah \\
\hline 16 & 15.30 & 2136 & $290,2^{\circ}$ & $25,5^{\circ}$ & cerah \\
\hline
\end{tabular}


Procedia of Engineering and Life Science Vol. 1. No. 2 Juni 2021

Seminar Nasional \& Call Paper Fakultas Sains dan Teknologi (SENASAINS 2nd)

Universitas Muhammadiyah Sidoarjo

\begin{tabular}{|l|c|c|c|c|c|}
\hline 17 & 16.00 & 2282 & $288,2^{\circ}$ & $18,5^{\circ}$ & Mendung \\
\hline 18 & 16.30 & 2036 & $286,6^{\circ}$ & $11,4^{\circ}$ & Mendung \\
\hline 19 & 17.00 & 2088 & $285,4^{\circ}$ & $4,2^{\circ}$ & Mendung \\
\hline \multicolumn{2}{|l}{ Rata - Rata } & 4891 & $226,2^{\circ}$ & $44,7^{\circ}$ & Cerah \\
\hline
\end{tabular}

Pada tabel 4. diatas didapatkan data pembacaan sensor lux pada kualitas intensitas cahaya dengan rata rata sebesar 4891 lux, dan berikut data grafik pengukuran lux pada cahaya matahari.

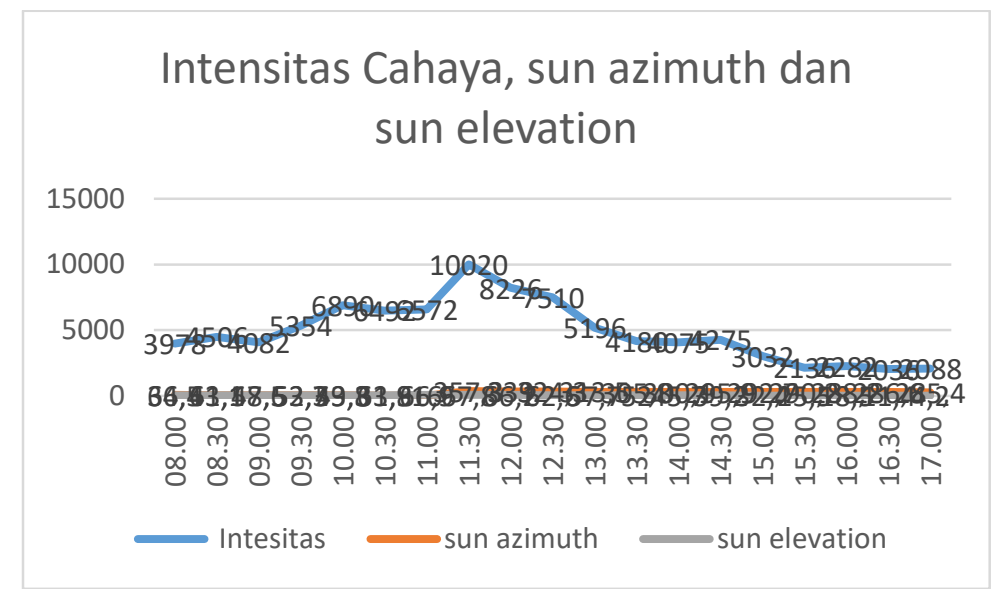

Gambar 11. Grafik Pengukuran Lux Pada Cahaya Matahari.

Dari gambar grafik 11. diatas didapatkan data bahwa semakin panas dari intensitas cahaya matahari maka semakin tinggi. Rata rata lux yang diukur selama 10 jam sebesar 3812, nilai tertinggi pada pukul 11.30 sebesar 10020 lux dan nilai lux terendah pada pukul 16.30 sebesar 2036 lux.

\section{KESIMPULAN}

Berdasarkan pengukuran, pengujian, perhitungan dan analis data pada PANEL PEMBANGKIT LISTRIK TENAGA MATAHARI DENGAN INSTALASI SISTEM ARUS SEARAH KENDALI JARAK JAUH BERBASIS ANDROID maka dapat disimpulkan bahwa kinerja dari sistem PLTS cukup efisien dengan menggunakan mikrokontroller NodeMCU ESP8266 dan daya PLTS menyuplai aliran listrik ke beban selama 10 jam dari pukul 08.00 - 17.00. Kemudian penggunaan media aplikasi blynk yang terhubung dengan internet yang mampu melakukan monitoring intensitas, arus dan tegangan pada sistem PLTS dan pengontrolan on dan off pada lampu dc secara jarak jauh jika melakukan berpergian sehingga memudahkan penggunanya. Sensor lux bh 1750 melakukan pembacaan intensitas cahaya matahari dengan baik . Sensor INA219 berfungsi secara baik dengan tingkat akurasi tegangan 96,5 - 97,8 \% dan arus sebesar 98-99\%. Keluaran daya pada PLTS berpengaruh dari panas cahaya matahari, jika semakin tinggi panas matahari saat cuacanya panas maka akan menghasilkan keluaran tegangan, arus dan daya yang tinggi, jika semakin cuaca mendung maka semakin rendah daya keluaran dari PLTS yang dihasilkan.

\section{REFERENSI}

[1] D. Dzulfikar and W. Broto, "Optimalisasi Pemanfaatan Energi Listrik Tenaga Surya Skala Rumah Tangga," vol. V, pp. SNF2016-ERE-73-SNF2016-ERE-76, 2016.

[2] A. Supriyadi, J. Jamaaluddin, T. Elektro, and U. Muhammadiyah, “Analisa Efisiensi Penjejak Sinar Matahari Dengan Menggunakan,” Jeee-U, vol. 2, no. APRIL, 2018, pp. 8-15, 2018.

[3] K. Akhmad, "Pembangkit Listrik Tenaga Surya Dan Penerapannya Untuk Daerah Terpencil,” J. Ilm. Din. Rekayasa, vol. 1, no. 1, pp. 28-33, 2005.

[4] Jamaaluddin, I. Robandi, and I. Anshory, "A very short-term load forecasting in time of peak loads using interval type-2 fuzzy inference system: A case study on java bali electrical system," J. Eng. Sci. Technol., vol. 14, no. 1, pp. 464-478, 2019.

[5] Jamaaluddin and S. Sumarno, "Perencanaan Sistem Pentanahan Tenaga Listrik Terintegrasi Pada Bangunan," J. Electr. Electron. Eng., vol. 1, no. 1, p. 29, 2017.

[6] P. Listrik, T. Surya, S. Rumah, T. Urban, and N. S. Kumara, "Pembangkit Listrik Tenaga Surya Skala Rumah Tangga Urban Dan Ketersediaannya Di Indonesia," Maj. Ilm. Teknol. Elektro, vol. 9, no. 1, 2010.

[7] K. Mata and K. Per, "Program Studi Teknik Elektro 2006," vol. 3, no. 031, pp. 1-8, 2006.

[8] Jamaaluddin, I. Robandi, and I. Anshory, "A very short-term load forecasting in time of peak loads using 
interval type-2 fuzzy inference system: A case study on java bali electrical system,” J. Eng. Sci. Technol., 2019.

[9] N. Hidayati, L. Dewi, M. F. Rohmah, and S. Zahara, "Prototype Smart Home Dengan Modul NodeMCU ESP8266 Berbasis Internet of Things (IoT)," Tek. Inform. Univ. Islam Majapahit, pp. 1-9, 2018.

[10] A. Bagus, "Pengukuran tegangan, arus dan daya listrik menggunakan perangkat telepon pintar," Eprints.Ums.Ac.Id, vol. 20, no. 2, pp. 4-7, 2019.

[11] H. T. Monda, F. Feriyonika, and P. S. Rudati, "Sistem Pengukuran Daya pada Sensor Node Wireless Sensor Network," Pros. Ind. Res. Work. Natl. Semin., vol. 9, pp. 28-31, 2018.

[12] D. Fisika and U. Diponegoro, "Rancang Bangun Sistem Kendali Pid Untuk Intensitas Cahaya Lampu Dc Menggunakan Mikrokontroler Arduino Uno,” Berk. Fis., vol. 22, no. 1, pp. 32-40, 2019. 